\title{
The Illocutionary Acts in the Receptionists' Conversation of Lumbini Luxury Villas and Spa
}

\author{
I Wayan Ana ${ }^{1}$, Hastining Rahayu Negara ${ }^{2}$ \\ \{wayan.ana@gmail.com¹, rahayu.negara@gmail.com²\} \\ ${ }^{12}$ Faculty of Letters, Universitas Warmadewa Denpasar-Bali, Indonesia
}

\begin{abstract}
This study concerns with the kinds illocutionary acts and the functions used by receptionists conversations at Lumbini Luxury Villas and Spa, Jimbaran. In collecting the data, researcher used field writing technique method of video recording and voice recording. The data analyzed according to their functions and the kinds of illocutionary act found in the receptionists conversation with the guests. The results showed that there were four kinds of illocutionary acts appears in those conversation with the guests, they are commissives appears 7 examples, constative appears 8 examples, directive appears in 3 examples, and acknowledgement appears in 4 examples. It can be concluded that the expressions which appear in the conversation were greeting, thanking, apologizing, giving information, description, suggesting, asking question, offering, and promising.
\end{abstract}

Keywords - Conversation, illocutionary acts, locution receptionist.

\section{Introduction}

When starting a new conversation with someone, unconsciously we were performing speech act, but it was oftenly ignored by speaker or listener, it is caused those speakers and listeners just focusing on the point of conversation. In fact, speech acts can be found and can be analyzed, in every communication, according to its types such as in the receptionist's conversation between guest at Lumbini Luxury Villas and Spa which always does a direct conversation as well as indirect conversation. It seems to be an interesting thing to be investigated and discussed.

In line with speech act, commonly it never be apart with pragmatics analysis. As what has suggested [1] that Pragmatics deals with the study of meaning as communicated by a speaker or a writer and interpreted by a listener or reader. This implies that Pragmatics is the study of speaker meaning since it deals more with what the speaker means by uttering than what the words or phrases in the utterance mean. It also implies that Pragmatics is the study of contextual meaning as it covers the interpretation of what people means in a particular context and how the context influences what is said. In addition, it has an implication that Pragmatics is the study of how more gets communicated than is said due to the fact that it investigates how listeners may draw inferences about what is said or what the speaker intends to say language and its users. Similarly, [2] that Pragmatics is a science that has something to do with language and its users. 
The other argument also has originally stated by Austin said that speech acts can be analyzed by three level namely locutionary acts: the performance of an utterance the actual utterance and its ostensible meaning, comprising phonetic, phatic, and rhetic acts corresponding to the verbal, syntactic, and semantic aspects of any meaningful utterance, llocutionary acts the pragmatic "illocutionary force" of the utterance, thus its intended significance as socially valid verbal action and cases a further, and perlocutionary acts its actual effect, such as persuading, convincing, scaring, enlightening inspiring, or otherwise getting someone to do realize something, whether intended or not.

Likewise, [3] speech act is an utterance that serves a function in communication. The acts are of various kinds such as making a statement, giving suggestion, offer an apology, greeting, request, complaint, invitation, compliment, or refusal. Speech acts are usually used in every sentence which is spoken or written. A verbal communication is a performing speech act. When people start a new conversation with other, they are unconsciously performing speech act. In fact, type of speech acts use in all aspect of daily life. In other words, locutionary act is an act of saying something, provides the listeners with the core of information from which to infer the speaker's illocutionary (communicative) intent [4].

Distinguishes three aspect of the locutionary act to say anything are: a) Always to perform the act of uttering certain noises. b) Always to perform the act of uttering certain vocable or words. c) generally to perform the act of using that (sentence) or its constituents with a certain more or less definite 'sense' and more or less reference.

Therefore, it can be concluded that component of locutionary acts in cluding phonetic (phonogy), phatic (syntactic), and rhetic (meaningful). [5] The locutionary act is recognizing that $\mathrm{S}$ has uttered an identified sentence $\sum$ from language $\mathrm{L}$ with an identified prosody $\phi$; in others words, the constituents and constituent structure of $\sum$ are recognized, and so are the sense of those constituent, and the sense or sense of $\sum$ itself. Thus, for our purpose, recognizing that $\sum$ spoken with prosody $\phi$ (are more simply). $\sum \phi$. Besides that as we know that when the speaker says something, it will make some effects to the listener. Thus effect may be in his emotion, attitude, or expression in his face. This is what we call as perlocutionary act where a speech act, as viewed at the level of its psychological consequences, such as persuading, convincing, scaring, enlightening, inspiring, or otherwise getting someone to do or realize something, for instance by the way, I have a CD of Debussy, would you like to borrow it? Its illocutionary function is an offer, while its intended perlocutionary effect might to impress the listener or to show a friendly attitude, or to encourage an interest in a particular type of music. The perlocutionary act (or just simply the perlocutionary) carried out by a speakers making an utterance is the act of causing a certain effect or the hearer and others [6]. If the speaker says "There's hornet in your left ear", it may cause the hearer to be panic, scream, and scratch wildly at the hearer's ear. Causing these emotions and actions of the hearer, it is the perlocutionary of the speaker's utterance, or the perlocutionary act of the speaker performed by making that utterance.

An illocutionary act is the pragmatic 'illocutionary force' of the utterance, thus its intended significance as a socially valid verbal action. The concept of an illocutionary act is central to the concept of a speech act. Although there are numerous opinions regarding how to define 'illocutionary acts', there are some kinds of acts are widely accepted as illocutionary, as for example promising, ordering somenone and questioning. The illocutionary act carried out by the speaker making an utterance is the act viewed in terms of the utterance significance within a conventional system of social interaction. Illocutionary are acts defined by social convention. The acts such as accosting, accusing, admitting, apologizing, challenging, complaining, condoling, congratulating, declining, deploring, giving permission, giving way, greeting, leave taking, mocking, ramming, offering, praising, promising, proposing marriage, protesting, recommending, surrendering, thanking, toasting [6]. 
Moreover, there were some previous researches who done related to this current issue. Firstly, [7] based on the findings and discussion, four classifications of speech acts are found from the data (teacher talk). The total of the utterances uttered by the teacher in one meeting of teaching and learning is 673 utterances. Four classifications have different portions, with directive speech acts as the dominant one, taking over $70 \%$ of the utterances. The second dominant classification is representative speech act for $21 \%$. The expressive and commissive speech acts have small portions, namely $6 \%$ and $3 \%$, respectively. The teacher argued that her reasons of using more directive speech acts are only to get students to talk more and to carry out the principle of Communicative Language Teaching as what she believes. Secondly, [8] the writer found that not all types of illocutionary acts occurred in the utterances of Chinese who live in Hos Cokroaminoto, Pematangsiantar. The types of illocutionary acts occurred in the utterances of Chinese who live in Hos Cokroaminoto, Pematangsiantar are Representative (typical of structure expressions of asking), Directive (typical of structure expressions of ordering and inviting), Expressive (typical of structure expressions of greeting and compliment), and Commissive (typical of structure expressions of threatening). Thirdly, [9] the data that is found in the video of Prabowo Vs Jokowi - Epic Rap Battles of Presidency shows that those all five categories are available in the video. There are 83 illocutionary acts in the video. The most frequently found are assertive with the total 41 or $49 \%$, and the lowest are commisive with the total 1 or $1 \%$. Directive acts were found in 14 utterances or $17 \%$, expressives acts were found in 17 utterances or $20 \%$ and declarative act were found in 11 utterances or $13 \%$. Based on to the general background being described above, this recent study aims are to identify the kinds of illocutionary acts and examine the functions of language that found in the conversation from the dialogues of the receptionist and the foreign guest at Lumbini Luxury Villas and Spa.

\section{Method}

The method used in this study is descriptive qualitative approach. The sources of data were taken from the receptionist while talking with the foreign guests. The data collected by using observation voice recording and video recording. In collecting the data, firstly researcher, as a key instrument, recorded the conversation between receptionist and the foreign guests, then analyzed by rewriting the conversation from the recording. After that those data collected were identified and classified into types of speech acts according to the theory applied, then the functions and expressions were descriptively analyzed based on the theory and the explanations.

\section{Results And Discussion}

In the following section, it would be explained some kinds of the illocutionary acts which were found in the receptionists conversation and the expressions which are commonly used by the receptionists at Lumbini Luxury Villas and Spa.

\subsection{The illocutionary act of Constatives performed by The receptionist}

Receptionist : now we are here (at the lobby), tomorrow breakfast here (pointing on the location of the restaurant at the back) start 7until 10.30 AM and for the lunch and dinner here last order 10 PM. Also we have pool, lounge, gym, and also minimart, so you can buy some 
food or drink special price for 1 hour 20\$ USD and 2 hours 35\$ USD. So if you want to book you can pay by rupiah.

Guest : Okay.

It can be seen from the conversation (a) by uttering the bold sentence. The expression used by the receptionist categoried as giving description, because the sentence describing an object, condition, or a place to be clearer and from its functions, this utterance is classified as referential function, because the sentence shows how the speaker giving a description of the location of the villa to the listener that contain with fact. By uttering this word, the receptionist expressed the descriptive to the guest by describing the map of the villa.

Guest : Where is the main pool?

Receptionist : The main pool is here (pointing to the location of the main pool). But in the villa is already provide by the private pool

Guest : Where is the main pool?

Receptionist : The main pool is here (pointing to the location of the main pool). But in the villa is already provide by the private pool.

From the conversation (c) by uttering the bold sentence. The expression used by the receptionist categorized as giving description, because the sentence describing an object, condition, or a place to be clearer. From its functions, this utterance is classified as referential function, because the sentence shows how the speaker giving a description of the location of the main swimming pool to the listener that contain with fact. In this circumstance, the receptionist expressed the descriptive to the guest by describing the location of the main swimming pool in the villa.

Guest $\quad:$ I have flight tonight at ten to eight. (07.50). so, what time should I go?

Receptionist : Aha! You should be there, normally 3 hours before your flight.

Guest : Oh three hours before.

It can be seen from the conversation (d) by uttering the bold sentence. The expression used by the receptionist categorized as giving suggestion, because the sentence tell about to mention forward for consideration or possible action. Fom its functions, this utterance is classified as emotive function, because the sentence shows the word Aha! Expresses sudden surprise the speaker got. In this condition, the receptionist expressed the suggesting to the guest that the guest should come to the airport 3 hours before their flight

Receptionist : You should be there. Okay, let see 07.50, so you should be there on 04.50

Guest : Oh ten to five?

Receptionist : I think 05.30 or 5.45 its okay.

Guest : Okay, at 05.45

In conversation (e) by uttering the bold sentence. The expression used by the receptionist categorized as giving suggestion, because the sentence tell about to mention forward for consideration or possible action. From its functions, this utterance is classified as conative function, because the sentence shows the imperative of suggesting, it shown by saying you should be there on 04.50. In this condition, the receptionist expressed the suggesting to the guest that the guest should come to the airport on 04.50

Guest : How long to take to the airport?

Receptionist : May be around 20 minutes to 30 minutes

Guest : That should be good. Let call it 5 (PM)

Receptionist : Sorry, I got an information that for the lunch, maybe you get information from Kelly, it will be charge personal

Guest : Okay, so I should pay the lunch

In conversation $(\mathrm{g})$ by uttering the bold sentence. The expression used by the receptionist categorized as giving information, because the speaker informs the listeners that propositions if speaker expresses the belief and the intention that the listener form the belief that proposition. From its functions, this utterance is classified as referential function, because the sentence is 
giving the real fact, it shown by saying I got an information that for the lunch, maybe you get information from Kelly, it will be charge personal. In this circumstance, the receptionist expressed giving information to the guest by informing the guest about the information receptionist got from Kelly (the guest who gave the information to the receptionist).

Receptionist : Yes, because in room number 111 if you be in 4 person for the lunch, I got an information around 25\$ USD.

Guest : Okay, 3 people in the room 111 not 4

Guest : Oh I just want to say, is there any way that I can have a late checkout?

Receptionist : Someone will stay in your room, so I think you can put your luggage here and you can still use the swimming pool. If you want to take a shower, you can ask for the towel here

Guest : Alright.

In conversation (i) by uttering the bold sentence. The expression used by the receptionist categories as giving information, because the speaker informs the listeners that propositions if speaker expresses the belief and the intention that the listener form the belief that proposition. From its functions, this utterance is classified as referential function, because the sentence is giving the real fact, it shown by saying Someone will stay in your room, so I think you can put your luggage here and you can still use the swimming pool. If you want to take a shower, you can ask for the towel here. In this circumstance, the receptionist expressed giving information to the guest by informing the guest about the room guest want to use is already reserve for another guest, so the guest cannot stay in the room if the guest want to late checkout.

Receptionist : So for the information, for the extra bed my friend still arrange and also for the extra bed will charge75\$ USD include the breakfast. Guest : Okay

In conversation (j) by uttering the bold sentence. The expression used by the receptionist categorized as giving information, because the speaker informs the listeners that propositions if speaker expresses the belief and the intention that the listener form the belief that proposition. From its functions, this utterance is classified as referential function, because the sentence is giving the real fact, it shown by saying So for the information, for the extra bed my friend still arrange and also for the extra bed will charge75\$ USD include the breakfast In this circumstance, the receptionist expressed giving information to the guest by informing the guest about the room guest want to use is still arranging the extra bed and the extra bed will be charge $75 \$$ USD including the breakfast.

\subsection{The illocutionary act of Commissives performed by The receptionist}

Receptionist : Okay, I will call you at 11.45. So for the bill, you want to pay now?

Guest : No, I just check it. So I will pay when I check out

In conversation (a) by uttering the bold sentence. The expression used by the receptionist categorized as promise because it makes. From its functions, this utterance is classified as conative function, because the sentence consists of the imperative of promise, it shown by saying I will call you at 11.45 . In this condition, the receptionist expressed the promising to the guest that the receptionist will call the guest at 11.45 .

Receptionist : It is okay, if you want to go swimming in the big swimming pool it is okay, maybe we have towel there. So you can keep your luggage here. When the room is ready, I will pick your luggage there.

Guest : Okay

In conversation (b) by uttering the bold sentence. The expression used by the receptionist categorized as promise. From its functions, this utterance is classified as conative function, because the sentence consists of the imperative of promise, it shown by saying I will pick your luggage there. In this condition, the receptionist expressed the promising to the guest that the receptionist will take the luggage of the guest to their room. 
Guest : When I send email, I already said for one extra bed when I coming, they will collect one extra bed.

Receptionist: wait a moment Ma'am, I will chech it first.

In conversation (c) by uttering the bold sentence. The expression used by the receptionist categorized as promise. From its functions, this utterance is classified as conative function, because the sentence consists of the imperative of promise, it shown by saying I will check it first. In this condition, the receptionist expressed the promising to the guest that the receptionist will check for the email from the guest for extra bed and payment.

Guest : Hi! I want to book a spa

Receptionist : Yes, booking a spa

Guest : Is it possible to booking at $110^{\text {"e }}$ clock?

Receptionist : Just a moment I'll check it for you. So, how many hours?

Guest : Just one (hours). When should I pay? We can pay right now?

Receptionist: Okay, do you want to change into 05.50?

Guest: Okay, very good. At 05.50 (PM)

In conversation (e) by uttering the bold sentence. The expression used by the receptionist categorized as offering something, because the speaker offers something to the hearer or listener for doing something or offers to get something. From its functions, this utterance is classified as conative function, because the sentence consists of the imperative of offer, it shown by saying do you want to change into 05.50 ? In this condition, the receptionist expressed the offering to the guest if the guest needs to change the time into 05.50.

Receptionist : Can I help you?

Guest : Bill please, we will go

Receptionist : Okay, I will call you at 11.45 . So for the bill, do you want to pay now?

Guest : No, I just check it. So I will pay when I check out

In conversation $(\mathrm{g})$ by uttering the bold sentence, the receptionist as the speaker performs the illocutionary act of commissives. The expression used by the receptionist categories as offering something, because the speaker offers something to the hearer or listener for doing something or offers to get something. Seen from the functions, this utterance is classified as conative function, because the sentence consists of the imperative of offer, it shown by saying do you want to pay now? In this condition, the receptionist expressed the offering to the guest if the guest want to pay the bill now or then.

\subsection{The illocutionary act of acknowledgement performed by The receptionist}

Receptionist : Hello

Guest : How are you?

Receptionist : I'm good, very good

In conversation (a) by uttering the bold sentence, the expression used by the receptionist categories as greeting, because the speaker doing an act of welcoming or saluting the listener. Seen from the functions, this utterance is classified as phatic function, because the word Hello shows how the speaker maintains the contact with the person who they are talking with. By uttering this word, the receptionist expressed the greeting to the guest by the politeness and welcoming the guest to the receptionist desk to start the conversation.

Receptionist : Welcome, you under name this?

Guest : Yes, that's right

In conversation (b) by uttering the bold sentence. The expression used by the receptionist categorized as greeting, because the speaker doing an act of welcoming or saluting the listener. From its functions, this utterance is classified as phatic function, because it consists of word Welcome, it shows how the speaker maintains the contact with the person who they are talking 
with. By uttering this word, the receptionist expressed the greeting to the guest by welcoming the guest to the receptionist desk to check in and doing the registration.

Receptionist : Hi, can I help you?

Guest : I'm in room 78, checkout on midday tomorrow. Now I'd like to extend. That was possible to go flight with some of them at the 8 o'clock and other will flight at midnight. So we could extend for a few hours. Can you help us?

Receptionist : Good Morning

Guest: Good Morning, we are from room 111. And we just want to arrange shuttle to airport for tomorrow

In conversation (d) by uttering the bold sentence, the expression used by the receptionist categories as greeting, because the speaker doing an act of welcoming or saluting the listener. From its function, this utterance is classified as phatic function, because it consists of word Good Morning it shows how the speaker maintains the contact with the person who they are talking with. By uttering this word, the receptionist expressed the greeting to the guest by welcoming the guest to the receptionist desk to start the conversation and asking something.

\subsection{The illocutionary act of Directives performed by The receptionist}

Receptionist : Until what time?

Guest : I don't know, can you tell me until what time you can? I will directly reserve it.

In conversation (a) by uttering the bold sentence, the expression used by the receptionist categorized as asking question, because the bold sentence followed by interjection which words are used to get an answer such as: what, why, who, where, when, do you, and a punctuation mark (?). From its functions, this utterance is classified as phatic function, because the word until what time? Shows how the speaker maintains the contact with the person who they are talking with by asking a question. By uttering this word, the receptionist expressed the greeting to the guest by the politeness and welcoming the guest to the receptionist desk to start the conversation.

Guest: Hi! I'm in room114. The swimming pool it seems that it's licking out (from) outside. So we on the bedroom side while you drink, there are water coming out (from) outside. Very slowly, but its spreading out which following the room

Receptionist : Licking in the inside or outside?

Guest: Outseide

In conversation (b) by uttering the bold sentence, the expression used by the receptionist categories as asking question, because the bold sentence followed by interjection which words are used to get an answer such as: what, why, who, where, when, do you, and a punctuation mark (?). From its function, this utterance is classified as phatic function, because the sentence Licking in the inside or outside? Shows how the speaker maintains the contact with the person who they are talking with by asking a question. By uttering this word, the receptionist expressed the asking question to the guest by responding the guest complained for the broken swimming pool. else?

Receptionist : Oh! On the left side. Let us send somebody to checking. Is there anything

Guest : No, just it. We will going outside. Maybe we'll be coming tonight to see it

In conversation (4) by uttering the bold sentence, te expression used by the receptionist categorized as asking question, because the bold sentence followed by interjection which words are used to get an answer such as: what, why, who, where, when, do you, and a punctuation mark (?). From its function, this utterance is classified as phatic function, because the sentence consists of interjections $\mathrm{Oh}$ ! Shows the speaker expresses sudden surprise. By uttering this 
word, the receptionist expressed the asking question to the guest by responding the guest complains for the broken swimming pool by sending technician

\section{Conclusion}

All the conversation between receptionists and guests at Lumbini Villas and Spa were found some of the illocutionary acts mostly used by the receptionists to the guest. The kind of communicative illocutionary acts found in the conversation are constative, directive, commissive, acknowledgement. The illocutionary acts found, such as greeting, thanking, apologizing, description, asking question, giving information, offering, promising, and suggesting. It is also found kinds of functions used when the receptionists making a conversation with the guest who came to the receptionist desk. The functions mostly used by the receptionist, such as referential function, emotive function, conative function, and phatic function. The metalingual function and poetic function did not found, because the conversation between the receptionists and the guests used the international language and it would be strange if the receptionists or the guests using a poetic word when communicate with each other

\section{Reference}

[1] G. Yule, Pragmatics. Oxford New York: Oxford University Press 1996, 1996.

[2] J. L. Mey, Pragmatics: An Introduction. Oxford: Blackwell Publisher, Inc, 1994.

[3] J. . Searle, Expression and Meaning. New York: Cambridge University Press, 1979.

[4] J. L. Austin, How to Do Things with Word. London: Oxford University Press, 1962.

[5] K. Allan, Linguistic Meaning. London: Routledge \& Kegan Poul, 1989.

[6] Heasly \& Hurford, Semantic a Course Book. London: Cambridge University Press, 1983.

[7] S. M. Basra and L. Thoyyibah, "A Speech Act Analysis of Teacher Talk in An Efl Classroom," International Journal of Education, vol. 10, no. 1, pp. 73-81, 2017.

[8] Herman, "Illocutionary Acts Analysis of Chinese in Pematangsiantar," International Journal of Humanities and Social Science Invention, vol. 4, no. 12, 2015.

[9] B. Rais and S. Triyono, "Pragmatic Analysis of Speech Acts on The Video of Prabowo Vs Jokowi - Epic Rap Battles Of Presidency," International Journal of Linguistics, Literature and Translation (IJLLT), vol. 2, no. 3, pp. 150-157, 2019 